\title{
REGULASI EMOSI MAHASISWA UNIVERSITAS BUANA PERJUANGAN (UBP) DALAM PEMBELAJARAN DARING PADA MASA PANDEMI COVID 19
}

\author{
Dinda Aisha
}

Email: dinda.aisha@ubpkarawang.ac.id

\author{
Fakultas Psikologi Universitas Buana Perjuangan Karawang
}

\begin{abstract}
The aim of this study is to describe emotion regulation condition of college students in University of Buana Perjuangan Karawang during online study. The total participant of this study is 118 consist of University of Buana Perjuangan Karawang college students year 2020. This study used quantitative description method with questionnaire as tools to gather data. The result of this study shows $76 \%$ participant has greater score of Cognitive Reappraisal than Expressive Suppression strategy of emotion regulation. It means that participant used to change what they think of certain situation to change emotion condition than to express the emotion. They tend to change how they see situation which elicit negative emotion in order to feel better especially when they regulate emotion during online class.
\end{abstract}

Keywords: Emotion Regulation; Covid 19; Cognitive Reappraisal; Expressive Suppresion

\begin{abstract}
Abstrak
Penelitian ini bertujuan untuk mengetahui gambaran regulasi emosi pada mahasiswa selama proses pembelajaran daring di Universitas Buana Perjuangan Karawang. Subjek penelitian ini berjumlah 118 mahasiswa Angkatan 2020 yang masih aktif berkuliah di Universitas Buana Perjuangan. Penelitian ini menggunakan metode kuantitatif deskriptif dengan teknik pengumpulan data berupa kuesioner. Hasil penelitian menunjukkan bahwa $76 \%$ respon dari partisipan menunjukkan Skor Cognitive Reappraisal > Skor Expressive Suppression. Hasil ini menunjukkan bahwa 76\% partisipan meregulasi emosi mereka khususnya selama proses pembelajaran daring dengan menggunakan strategi Cognitive Reappraisal, yang berarti partisipan lebih condong untuk mengubah pemaknaan akan suatu situasi agar mengurangi emosi negatif yang muncul dibandingkan untuk mengekspresikan emosi tersebut. Dapat disimpulkan bahwa $76 \%$ partisipan lebih memilih meregulasi emosi mereka dengan cara mengubah cara berpikir akan suatu situasi yang memunculkan emosi negatif. Partisipan juga akan mengubah cara berpikir akan suatu situasi apabila ingin merasakan emosi yang lebih positif. Mereka cenderung kurang dapat mengekspresikan emosi baik emosi negatif maupun emosi positif.
\end{abstract}

Kata Kunci: Regulasi Emosi; Covid 19; Cognitive Reappraisal; Expressive Suppression. 


\section{PENGANTAR}

Pada tanggal 09 Maret 2020, World Health Organization (WHO) atau Lembaga Kesehatan Dunia menyatakan bahwa Virus Covid-19 sebagai pandemi atau virus ini terjadi dan menjangkiti manusia secara luas di dunia. Dengan adanya pandemi virus Covid-19 ini, membuat warga dunia perlu beradaptasi dan mengubah gaya hidup seperti menerapkan $3 \mathrm{M}$ (Mencuci Tangan, Memakai Masker dan Menjaga Jarak), diterapkan sistem Work From Home (WFH) atau bekerja dari rumah serta School From Home (SFH) atau sekolah dari rumah. Adanya perubahan kebijakan ini membuat warga dunia, termasuk masyarakat Indonesia perlu melalui proses adaptasi yang tidak mudah. Mulai dari wajib menggunakan masker ketika keluar rumah, membatasi diri untuk berkumpul dan bepergian, serta digalakkannya pola hidup sehat.

Tak terkecuali dalam dunia Pendidikan. Menurut Surat Edaran Mendikbud Nomor 36962/MPK.A/HK/2020 diperintahkan supaya setiap proses belajar mengajar di sekolah maupun di Perguruan Tinggi menggunakan metode daring sebagai upaya pencegahan penyebaran Virus Covid-19. Metode daring ini bukanlah metode yang sudah dipelajari secara detail sebelumnya, namun setiap institusi Pendidikan perlu beradaptasi untuk mempersiapkan metode pembelajaran daring ini. Yang pasti, aturan ini mengharuskan para siswa dan mahasiswa melakukan proses belajar mengajar dari rumah melalui metode daring.

Di Universitas Buana Perjuangan Karawang, khususnya di Fakultas Psikologi juga diberlakukannya sistem pembelajan daring, dimana para dosen mengajarkan materi-materi pengajaran melalui media-media daring. Tentu saja, ada kelebihan dan kekuranganya. Adapun kelebihannya adalah baik tenaga pengajar maupun para mahasiswa menjadi lebih melek terhadap teknologi, lebih kreatif karena dituntut untuk bisa beradaptasi dengan keadaan serta diajarkan untuk lebih mandiri dalam proses belajar serta tidak perlu mengeluarkan biaya transportasi. Adapun keluhan-keluhan yang sering didengar oleh peneliti melalui mahasiswa yang diajarkan selama pengajaran daring adalah adanya kendala jaringan, kendala perangkat gawai, tidak ada kuota internet sehingga tidak bisa terhubung secara daring, biaya bulanan untuk kuota internet yang harus dikeluarkan, lebih mudah bosan karena kurangnya interaksi langsung dengan pengajar maupun teman, lebih sulit menerima materi melalui pembelajaran daring, dan lain sebagainya. Dari hasil penelitian yang dilakukan oleh Jannah \& Santoso (2021), mengatakan bahwa pembelajaran daring pada masa pandemi Covid-19 ini cukup memicu stres pada mahasiswa. Salah satu penyebabnya adalah faktor eksternal seperti kurang efektif saat penyampaian materi, lingkungan rumah yang tidak kondusif seperti berisik, dll.

Dari fenomena dan penjelasan di atas menunjukkan bahwa pembelajaran daring tentunya memberikan dampak bagi para mahasiswa dan butuh adanya proses adaptasi untuk dapat menghadapinya dengan baik. Untuk dapat menjalankan proses belajar mengajar daring yang efektif, dibutuhkan pengelolaan emosi yang baik pula agar mahasiswa tidak mengalami stres dan cemas dalam proses pembelajaran daring. Melihat pentingnya regulasi emosi pada mahasiswa, membuat peneliti tertarik untuk melihat bagaimana gambaran regulasi emosi pada mahasiswa Universitas Buana Perjuangan ketika melakukan proses pembelajaran daring selama masa pandemi Covid-19. 


\section{LANDASAN TEORI}

Menurut Gross dan Thompson (2007), regulasi emosi merupakan suatu istilah yang tidak mudah untuk didefinisikan. Secara harfiah, regulasi emosi adalah bagaimana seseorang meregulasi emosi seperti meregualasi pikiran, fisik dan perilaku yang dipengaruhi oleh emosi. Namun, definisi yang lebih tepat yaitu suatu rangkaian proses yang heterogen dimana emosi itu terregulasi. Proses dalam regulasi emosi ini dapat terjadi secara otomatis maupun dikontrol, disadari maupun tidak disadari dan dapat memberikan efek pada satu poin atau bahkan lebih (Gross \& Thompson, 2007). Gross dan John (2003) membagi 2 cara seseorang dapat meregulasi emosinya yaitu cognitive reappraisal dan expressive suppression:

1. Cognitive Reappraisal

Strategi ini melibatkan pengontrolan diri dalam segi kognitif dimana terdapat 2 hal yang diregulasi yaitu mengontrol atensi dan mengubah secara kognitif arti dari stimulus yang menimbulkan suatu emosi tertentu. Menurut Gross dan John (2003) dalam Cutuli (2014), sebuah upaya untuk mengubah interpretasi terhadap suatu situasi yang memunculkan emosi tertentu sehingga mengubah arti dari situasi itu dan memberikan perubahan emosi yang menjadi lebih baik.

2. Expressive Suppression

Menurut Gross dan John (2003) dalam Cutuli (2014), expressive suppression adalah suatu upaya untuk menyembunyikan, menekan dan mengurangi perilaku untuk mengeskpresikan emosi.

\section{METODE PENELITIAN}

Metode penelitian pada penelitian ini menggunakan metode deskriptif kuantitatif, yang mana metode ini dapat menggambarkan kondisi subjek apa adanya. Penelitian ini dilakukan di Karawang dengan jumlah sampel sebanyak 118 mahasiswa Universitas Buana Perjuangan Karawang Angkatan 2020 yang masih aktif kuliah dan sedang melakukan perkuliahan daring. Penelitian ini menggunakan skala regulasi emosi diambil dan diterjemahkan dari diterjemahkan dari Emotion Regulation Questionnaire yang didesain oleh Gross \& John tahun 2003 yang mana bertujuan untuk menilai kemampuan individu pada situasi sehari-hari dalam penggunaan 2 strategi regulasi emosi yaitu cognitive reappraisal dan expressive suppression. Skala ini terdiri dari 10 pernyataan 6 merupakan aitem cognitive reappraisal dan 4 merupakan aitem expressive suppresion dengan pilihan jawaban mengunakan skala Likert dari 1 sampai 7 dengan rentang Sangat Tidak Setuju, Netral dan Sangat Setuju. Penelitian ini menggunakan statistik deskriptif yaitu statistic yang digunakan untuk menganalisis data dengan cara mendeskripsikan atau menggambarkan data yang telah terkumpul sebagaimana adanya tanpa bermaksud membuat kesimpulan yang berlaku untuk umum atau generalisasi (Sudaryono, 2019). Data dianalisis menggunakan teknik persentase.

\section{HASIL DAN PEMBAHASAN}

\section{Hasil}

Data penelitian ini didapatkan dari kuesioner regulasi emosi dari Gross dan John (2003) dengan tujuan untuk mengetahui gambaran strategi yang digunakan dalam melakukan regulasi emosi yang digunakan oleh mahasiswa Universitas Buana Perjuangan khususnya dalam proses pembelajaran daring di masa pandemik Covid 
19 ini. Jumlah butir pada kuesioner ini adalah 10 pernyataan dengan 7 pilihan alternatif jawaban. Kuesioner ini membagi strategi regulasi emosi menjadi 2 yaitu cognitive reappraisal dan expressive suppression. Setiap butir pernyataan terdiri dari 7 alternatif jawaban mulai dari sangat setuju sekali sampai sangat tidak setuju sekali. Instrumen berupa kuesioner ini diberikan kepada mahasiswa Universitas Buana Perjuangan Karawang Angkatan 2020 yang berjumlah 118 orang. Analisis dalam penelitian ini dengan cara mengamati hasil data dari skor menggunakan teknik persentase.

Regulasi emosi dapat dilihat dari strategi regulasi emosi yang digunakan oleh seseorang dalam menghadapi suatu situasi yang menantang, salah satunya adalah dalam proses pembelajaran daring selama masa pandemik Covid-19 ini. Adapun 2 strategi regulasi emosi yang diukur dalam penelitian ini berdasarkan kuesioner yang digunakan yaitu cognitive reappraisal dan expressive suppression. Lebih lanjut untuk mengetahui data yang diperoleh melalui strategi yang digunakan sebagai berikut:

\section{Strategi regulasi emosi - Cognitive Reappraisal}

Strategi ini melibatkan pengontrolan diri dalam segi kognitif dimana seseorang berusaha mengontrol atensi dan mengubah secara kognitif arti dari stimulus yang menimbulkan suatu emosi tertentu muncul serta sebuah upaya untuk mengubah interpretasi terhadap suatu situasi yang memunculkan emosi tertentu sehingga mengubah arti dari situasi itu dan memberikan perubahan emosi yang menjadi lebih baik (Gross dan John, 2003 dalam Cutuli, 2014). Data yang diperoleh setelah dilakukan penelitian dapat dilihat pada tabel di bawah ini:

Tabel 1. Tabel Strategi Regulasi Emosi- Cognitive Reappraisal

\begin{tabular}{|c|c|c|c|c|c|c|c|c|}
\hline No. & $\begin{array}{l}\text { Strategi regulasi emosi- } \\
\text { Cognitive Reappraisal }\end{array}$ & $\begin{array}{l}\text { Sangat } \\
\text { Setuju } \\
\text { Sekali }\end{array}$ & $\begin{array}{l}\text { Sangat } \\
\text { Setuju }\end{array}$ & Setuju & Netral & $\begin{array}{l}\text { Tidak } \\
\text { Setuju }\end{array}$ & $\begin{array}{l}\text { Sangat } \\
\text { Tidak } \\
\text { Setuju }\end{array}$ & $\begin{array}{c}\text { Sangat } \\
\text { Tidak } \\
\text { Setuju } \\
\text { Sekali }\end{array}$ \\
\hline 1 & 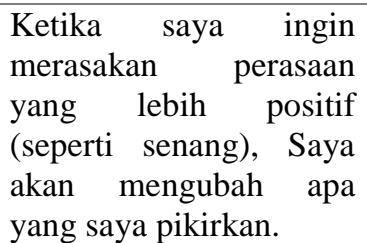 & $\begin{array}{l}17 \\
(14,4 \%)\end{array}$ & $\begin{array}{l}33 \\
(28 \%)\end{array}$ & $\begin{array}{l}44 \\
(37,3 \%)\end{array}$ & $\begin{array}{l}15 \\
(12,7 \%)\end{array}$ & $6(5,1 \%)$ & $1(0,8 \%)$ & $2(1,7 \%)$ \\
\hline 2 & $\begin{array}{l}\text { Ketika saya ingin } \\
\text { mengurangi perasaan } \\
\text { negatif (seperti sedih } \\
\text { atau marah), saya akan } \\
\text { mengubah apa yang } \\
\text { saya pikirkan }\end{array}$ & $13(11 \%)$ & $\begin{array}{l}29 \\
(24,6 \%)\end{array}$ & $\begin{array}{l}51 \\
(43,2 \%)\end{array}$ & $\begin{array}{l}19 \\
(16,1 \%)\end{array}$ & $5(4,2 \%)$ & $1(0,8 \%)$ & $0(0 \%)$ \\
\hline 3 & $\begin{array}{l}\text { Ketika saya dihadapi } \\
\text { pada situasi yang penuh } \\
\text { tekanan, saya akan } \\
\text { memikirkannya dengan } \\
\text { cara yang dapat } \\
\text { menenangkan diri saya. }\end{array}$ & $26(22 \%)$ & $\begin{array}{l}38 \\
(32,2 \%)\end{array}$ & $\begin{array}{l}39 \\
(33,1 \%)\end{array}$ & $\begin{array}{l}12 \\
(10,2 \%)\end{array}$ & $2(1,7 \%)$ & $1(0,8 \%)$ & $0(0 \%)$ \\
\hline 4 & $\begin{array}{lr}\text { Ketika saya ingin } \\
\text { memiliki emosi } & \text { yang } \\
\text { lebih positif, saya } & \text { akan } \\
\text { mengubah cara } & \text { saya } \\
\text { memikirkan } & \text { suatu } \\
\text { situasi. } & \end{array}$ & $\begin{array}{l}15 \\
(12,7 \%)\end{array}$ & $\begin{array}{l}25 \\
(21,2 \%)\end{array}$ & $\begin{array}{l}53 \\
(44,9 \%)\end{array}$ & $\begin{array}{l}20 \\
(16,9 \%)\end{array}$ & $4(3,4 \%)$ & $0(0 \%)$ & $1(0,8 \%)$ \\
\hline
\end{tabular}




\begin{tabular}{|c|c|c|c|c|c|c|c|c|}
\hline 5 & $\begin{array}{l}\text { Saya mengontrol emosi } \\
\text { saya dengan cara } \\
\text { mengubah pola pikir } \\
\text { saya terhadap suatu } \\
\text { situasi. }\end{array}$ & $\begin{array}{l}15 \\
(12,7 \%)\end{array}$ & $\begin{array}{l}29 \\
(24,6 \%)\end{array}$ & $\begin{array}{l}55 \\
(46,6 \%)\end{array}$ & $\begin{array}{l}13 \\
(11 \%)\end{array}$ & $5(4,2 \%)$ & $0(0 \%)$ & $1(0,8 \%)$ \\
\hline 6 & $\begin{array}{l}\text { Ketika saya ingin } \\
\text { mengurangi perasaan } \\
\text { negatif, saya akan } \\
\text { mengubah cara berpikir } \\
\text { saya terhadap suatu } \\
\text { situasi. }\end{array}$ & $\begin{array}{l}11 \\
(9,3 \%)\end{array}$ & $\begin{array}{l}19 \\
(16,1 \%)\end{array}$ & $\begin{array}{l}70 \\
(59,3 \%)\end{array}$ & $\begin{array}{l}14 \\
(11,9 \%)\end{array}$ & $4(3,4 \%)$ & $0(0 \%)$ & $0(0 \%)$ \\
\hline
\end{tabular}

Dari data tabel 1, dapat dilihat bahwa untuk mendapatkan informasi terkait strategi regulasi emosi, dapat dilihat dari 6 aitem pernyataan seperti yang tertera pada tabel 1. Sebanyak 37,3\% responden mengatakan setuju bahwa cara mereka agar dapat merasakan perasaan yang positif adalah dengan mengubah apa yang mereka pikirkan. Sedangkan $5,1 \%$ menyatakan bahwa mereka tidak setuju dengan pernyataan ini. Selain itu 43,2\% responden menyetujui bahwa agar dapat mengurangi perasaan negatif, maka mereka akan mengubah pikiran yang menimbulkan perasaan negatif tersebut. Sedangkan 4,2\% tidak setuju dengan pernyataan ini. Sebanyak $33,1 \%$ partisipan setuju ketika mereka dihadapkan pada situasi yang penuh tekanan, maka mereka akan memikirkan hal lain yang dapat menenangkan diri mereka, dan hanya 1,7\% yang tidak setuju dengan pernyataan ini. Serta sebanyak 46,6\% partisipan juga setuju bahwa mereka mampu mengontrol emosi dengan cara mengubah pola pikir terhadap suatu situasi tertentu.

\section{Strategi regulasi emosi - Expressive Suppression}

Strategi ini melibatkan suatu upaya untuk menyembunyikan, menekan dan mengurangi perilaku dalam mengeskpresikan emosi. Strategi ini merupakan strategi yang berfokus pada respon. Secara garis besar, strategi ini memodifikasi aspek perilaku yang muncul dari respon emosi seseorang, tanpa menurunkan pengalaman dari emosi negatif tersebut.

Tabel 2. Tabel Strategi Regulasi Emosi- Expressive Suppression

\begin{tabular}{|c|c|c|c|c|c|c|c|c|}
\hline No. & $\begin{array}{l}\text { Strategi regulasi emosi- } \\
\text { Expressive Suppression }\end{array}$ & $\begin{array}{l}\text { Sangat } \\
\text { Setuju } \\
\text { Sekali }\end{array}$ & $\begin{array}{l}\text { Sangat } \\
\text { Setuju }\end{array}$ & Setuju & Netral & $\begin{array}{l}\text { Tidak } \\
\text { Setuju }\end{array}$ & $\begin{array}{l}\text { Sangat } \\
\text { Tidak } \\
\text { Setuju }\end{array}$ & $\begin{array}{l}\text { Sangat } \\
\text { Tidak } \\
\text { Setuju } \\
\text { Sekali }\end{array}$ \\
\hline 1 & $\begin{array}{l}\text { Saya memendam } \\
\text { perasaan saya }\end{array}$ & $\begin{array}{l}16 \\
(13,6 \%)\end{array}$ & $\begin{array}{l}24 \\
(20,3 \%)\end{array}$ & $\begin{array}{l}45 \\
(38,1 \%)\end{array}$ & $\begin{array}{l}23 \\
(19,5 \%)\end{array}$ & $6(5,1 \%)$ & $0(0 \%)$ & $\begin{array}{l}4 \\
(3,4 \%)\end{array}$ \\
\hline 2 & $\begin{array}{l}\text { Ketika saya merasa } \\
\text { emosi yang positif, saya } \\
\text { sangat berhati-hati untuk } \\
\text { tidak } \\
\text { mengekspresikannya }\end{array}$ & $7(5,9 \%)$ & $7(5,9 \%)$ & $\begin{array}{l}35 \\
(29,7 \%)\end{array}$ & $\begin{array}{l}34 \\
(28,8 \%)\end{array}$ & $\begin{array}{l}25 \\
(21,2 \%)\end{array}$ & $\begin{array}{l}4 \\
(3,4 \%)\end{array}$ & $\begin{array}{l}6 \\
(5,1 \%)\end{array}$ \\
\hline 3 & $\begin{array}{l}\text { Saya mengatur emosi } \\
\text { saya dengan cara tidak } \\
\text { mengekspresikannya }\end{array}$ & $9(7,6 \%)$ & $\begin{array}{l}11 \\
(9,3 \%)\end{array}$ & $\begin{array}{l}30 \\
(25,4 \%)\end{array}$ & $\begin{array}{l}33 \\
(28 \%)\end{array}$ & $\begin{array}{l}27 \\
(22,9 \%)\end{array}$ & $\begin{array}{l}5 \\
(4,2 \%)\end{array}$ & $\begin{array}{l}3 \\
(2,5 \%)\end{array}$ \\
\hline 4 & $\begin{array}{l}\text { Ketika saya merasakan } \\
\text { emosi negatif, saya harus } \\
\text { memastikan bahwa saya } \\
\text { tidak } \\
\text { mengekspresikannya }\end{array}$ & $\begin{array}{l}11 \\
(9,3 \%)\end{array}$ & $\begin{array}{l}15 \\
(12,7 \%)\end{array}$ & $\begin{array}{l}47 \\
(39,8 \%)\end{array}$ & $\begin{array}{l}27 \\
(22,9 \%)\end{array}$ & $\begin{array}{l}14 \\
(11,9 \%)\end{array}$ & $\begin{array}{l}2 \\
(1,7 \%)\end{array}$ & $\begin{array}{l}2 \\
(1,7 \%)\end{array}$ \\
\hline
\end{tabular}


Dari data tabel 2, dapat dilihat bahwa untuk mendapatkan informasi terkait strategi regulasi emosi dengan expressive suppresion, dapat dilihat dari 4 aitem pernyataan seperti yang tertera pada tabel 2 . Sebanyak $38,1 \%$ responden atau setara dengan 45 orang mengatakan bahwa mereka setuju bahwa mereka cenderung memendam perasaan mereka. Hal ini sejalan dengan informasi bahwa sebanyak 29,7\% responden mengatakan bahwa mereka berhati-hati dalam mengekspresikan perasaan positif dan sebanyak $21,1 \%$ mengatakan bahwa ketika mereka merasakan perasaan positif, maka mereka akan mengekspresikannya. Sejalan pula dengan pernyataan selanjutnya yaitu sebanyak $39,8 \%$ responden mengatakan bahwa ketika mereka merasaan emosi negatif, maka mereka memastikan untuk tidak mengekspresikannya.

\section{Pembahasan}

Di bawah ini merupakan hasil olah data penjumlahan skor dari masing-masing partisipan dengan ketentuan skoring yaitu pernyataan akan mendapatkan nilai 1 apabila responden memilih sangat tidak setuju sekali, nilai 2 apabila memilih sangat tidak setuju, nilai 3 apabila memilih tidak setuju, nilai 4 apabila memilih jawaban netral, nilai 5 apabila memilih setuju, nilai 6 apabila memilih sangat setuju dan nilai 7 apabila memilih sangat setuju sekali. Dari hasil pengolahan dan penjumlahan skor didapatkan data yang tertera pada tabel 3 sebagai berikut:

Tabel 3. Ringkasan Kecenderungan Strategi yang Digunakan

\begin{tabular}{llll}
\hline Jumlah & Skor Cognitive & Skor Cognitive & Skor Cognitive \\
Responden & $\begin{array}{l}\text { Reappraisal }>\text { Skor } \\
\text { Expressive }\end{array}$ & $\begin{array}{l}\text { Reappraisal } \\
\text { Expressive } \\
\text { Suppression }\end{array}$ & $\begin{array}{l}\text { Reappraisal } \\
\text { Supression }\end{array}$ \\
& $76 \%$ & $17 \%$ & $\begin{array}{l}\text { Skor Expressive } \\
\text { Suppression }\end{array}$ \\
\hline 118 & $76 \%$ & $7 \%$
\end{tabular}

Dari data yang tertera pada tabel 3 dapat disimpulkan bahwa sebanyak $76 \%$ responden lebih memilih menggunakan strategi regulasi emosi berupa meregulasi emosi dengan cara berusaha untuk mengontrol kognitif atau apa yang dipikirkan sehingga dapat mengubah interpretasi akan suatu situasi dan diikuti oleh perubahan emosi negatif yang muncul.

Dari hasil pengolahan data yang tertera pada tabel 1, 2 dan 3, dapat disimpulkan bahwa dalam menghadapi pembelajaran daring, para responden yang merupakan mahasiswa Angkatan 2020 yang pada saat pengambilan data sedang mengikuti perkuliahan di semester 2 lebih cenderung memilih menggunakan strategi Cognitive Reappraisal dalam meregulasi emosi yang muncul selama proses pembelajaran daring. Mereka cenderung lebih memilih mengubah sudut pandang atau cara berpikir mereka dari suatu situasi yang menimbulkan emosi negatif menjadi lebih positif. Partisipan lebih condong untuk mengubah pemaknaan akan suatu situasi agar mengurangi emosi negatif dan meningkatkan emosi positif dibandingkan mengekspresikan emosi baik negatif maupun positif, khususnya emosi-emosi yang muncul dari proess pembelajaran daring selama pandemic Covid-19 ini.

\section{KESIMPULAN}

Pandemik Covid 19 yang dialami oleh seluruh masyarakat yang ada di dunia sejak tahun 2020 awal telah banyak memberikan dampak dan perubahan di berbagai 
aspek kehidupan. Mulai dari segi ekonomi, bisnis, kesehatan, pendidikan, sampai ke gaya hidup. Salah satu sektor yang terdampak perubahan ini adalah segi Pendidikan, dimana para siswa maupun mahasiswa diharuskan untuk mengikuti pembelajaran dari rumah melalui media online atau disebut dengan pembelajaran daring atau pembelajaran jarak jauh. Dengan adanya perubahan yang mendadak baik dari situasi belajar yang kurang ideal, perangkat yang tidak memadai, kesulitan untuk mengikuti pembelajaran, dan lain sebagainya pastinya menimbulkan ketidaknyamanan yang memicu munculnya berbagai emosi khususnya emosi negatif seperti kesedihan, kemarahan, kekecewaan, kekesalan, kebosanan, dan lain-lain.

Untuk mengurangi dampak dari munculnya emosi negatif ini baik bagi diri sendiri maupun orang lain adalah dengan cara mengaturnya atau meregulasinya. Menurut Gross dan John (2003) terdapat 2 strategi seseorang dalam melakukan regulasi emosi yaitu Cognitive Reappraisal dan Expressive Suppression. Dari hasil penelitian yang dilakukan pada mahasiswa Universitas Buana Perjuangan Karawang Angkatan 2020 berjumlah 118, disimpulkan bahwa 76\% partisipan lebih memilih menggunakan strategi Cognitive Reappraisal dalam meregulasi emosi khususnya selama proses pembelajaran daring pada masa Pandemi Covid-19 ini. Partisipan lebih memilih meregulasi emosi mereka dengan cara mengubah cara berpikir akan suatu situasi yang memunculkan emosi negatif. Partisipan juga akan mengubah cara berpikir akan situasi apabila ingin merasakan emosi yang lebih positif. Mereka cenderung kurang dapat mengekspresikan emosi baik emosi negatif maupun emosi positif.

\section{REFERENSI}

Andiarna F., \& Kusumwati E. (2020). Pengaruh pembelajaran daring terhadap stres akademik mahasiswa selama pandemi covid-19. Jurnal Psikologi, 15(2), 139149.

Aryansah J. E., \& Sari, S. P. (2021). Analisis peran regulasi emosi mahasiswa terhadap kebijakan school from home di masa pandemi covid 19. Jurnal Pemerintahan dan Politik, 6(1). 8-14

Bericat, E. (2012). Emotions. (online). Tersedia: https://core.ac.uk/download/pdf/51410166.pdf (Mei 2021)

Cutuli, D. (2014). Cognitive Reapprasila and Expressive Suppression Strategies Role in the Emotion Regulation. Frontiers in Systems Neuroscience, 8. 175. 1-6

Davis, M., Eshelman, E. R., \& M'Kay, M. (2008). The relaxation \& stres reduction workbook $6^{\text {th }}$ edition. Oakland: New Harbinger Publications, Inc

Gillespie S. M., \& Beech A. R. (2016). Theories of emotion regulation. University of Birmingham: UK. 245-264

Goleman, D. (1995). Emotional intelligence: Kecerdasan emosional. PT Gramedia: Jakarta

Gross J., \& Thompon, R. A. (2007). Emotion regulation: Conceptual foundations. Hanbook of Emotion Regulation, 3-27 
Handayani D., Hadi D. R., Isbaniah F., Burhan E., \& Agustin H. (2020). Penyakit Virus Corona 2019. Jurnal Respirologi Indonesia, 40(2). 119-129

Hasanah U., Ludiana, I. L. (2020). Gambaran Psikologis Mahasiswa Dalam Proses Pembelajaran Selama Pandemi Covid-19. Jurnal Keperawatan Jiwa, 8(3). 299-306

Jannah., \& Santoso (2021). Tingkat stres mahasiswa mengikuti pembelajaran daring pada masa pandemi covid-19. Jurnal Riset dan Pengabdian Masyarakat, $1(1), 130-146$.

Mauss, I. B., Levenson, R. W. McCarter, L., Wilhelm, F. H., Gross, J. J. (2005). The tie that binds? Coherence among emotion experience, behavior, and physiology. Emotion, 5, 175-190.

Nopiyanti, S., Simatupang, M., \& Mubina, N. (2021). Pengaruh inferiority feeling terhadap kecenderungan melakukan kekerasan dalam berpacaran pada dewasa awal di Karawang. Jurnal Psikologi Prima, 4(1), 42-52.

Ochsner, K. \& Gross, J. J. (2005). The cognitive control of emotion. Trends in Cognitive Sciences, 9, 242-249.

Rusmaladewi, Indah, D., Kamala, I. \& Anggraini, H. (2020). Regulasi emosi pada mahasiswa selama proses pembelajaran daring di program studi PG-PAUD FKIP UPR. Jurnal Pendidikan dan Psikologi Pintar Harati, 16(2).

Simatupang, M. (2019). Kebahagiaan pada wanita plari depo (Studi kualitatifdeskriptif di Nusa Tenggara Timur). Psychopedia Jurnal Psikologi Universitas Buana Perjuangan Karawang, 4(1),

Sudaryono. (2019). Metodologi penelitian: Kuantitatif, kualitatif, dan mix method. Edisi Kedua. Depok: PT RajaGrafindo Persada

Wulan, D. A. N., \& Abdullah, S. M. (2014). Prokrastinasi akademik dalam penyelesaian skripsi. Jurnal Sosio-Humaniora, 5(1), 55 - 74

Yuliana. (2020). Corona Virus disease (Covid-19): Sebuah tinjauan literatur. Wellness and healthy magazine, 2(1). 187-192 